\title{
APRESENTAÇÃO: ESTADO E POLÍTICAS PÚBLICAS: DE QUE ESTAMOS FALANDO?
}

\author{
Celina Soura \\ Professora e Pesquisadora do IESP-UERJ
}

O tema ou a subárea de políticas públicas ganhou relevância em todas as disciplinas acadêmicas e em espaços técnicos e profissionais. Contudo, a discussão sobre o Estado e seu papel, assim como sua relação com as políticas públicas foi praticamente ignorada nos últimos anos. Parte dessa ausência pode ser explicada pela origem acadêmica dos dois temas. O do Estado sempre foi mais afeto ao debate europeu e o das políticas públicas ao norte-americano, este último exercendo, nas últimas décadas, grande influência na academia brasileira. Por isso, é muito salutar a iniciativa dos mestrandos em Ciência Política da UFPR e da Revista do programa - Revista Eletrônica de Ciência Política - de dedicar um dossiê ao tema Estado e Políticas Públicas.

Para melhor situar esse debate e buscar entender a relação entre Estado e políticas públicas é necessário começar pela definição de Estado para além do seu sentido weberiano ou de significados funcionalistas. Por Estado entendo o conjunto de instituições criadas, recriadas e moldadas para administrar conflitos e tensões dentro de um determinado território e sobre um determinado conjunto demográfico. O Estado é, portanto, o centro do poder político e de autoridade. Mas é preciso também avançar para incorporar uma definição de Estado democrático. Isso porque a formulação de políticas públicas constituise no estágio em que os governos democráticos traduzem seus propósitos e plataformas eleitorais em programas e ações, que produzirão resultados ou mudanças no mundo real.

O Estado democrático pode ser entendido como aquele fundado em torno de uma barganha política que reflete a relação contraditória entre diferentes forças sociais. Nessa abordagem, as instituições são os instrumentos de mediação de conflitos inerentes a uma barganha em torno de forças e de interesses contraditórios. É a partir das instituições do Estado que as políticas públicas são negociadas, formuladas e implementadas. Ou seja, a formulação e a implementação de políticas públicas em Estados democráticos é tarefa complexa e requer uma intricada engenharia institucional.

As instituições clássicas do Estado - Executivo ou governo nacional, Legislativo, Judiciário, governos subnacionais, administração pública, burocracia e forças militares têm, nos Estados democráticos, maior ou menor participação no processo decisório das políticas públicas. Não é por acaso, portanto, que se afirma que as políticas públicas representam o Estado em ação. Complexas por si mesmas e mais ainda quando articuladas 
para a tomada de decisão, essas instituições do Estado representam os principais loci onde negociações e barganhas em torno das políticas públicas são realizadas.

Mas não só o Estado e suas instituições influenciam as decisões sobre políticas públicas. Em sociedades democráticas e em sistemas capitalistas, grupos de interesses organizados, que representam tanto a sociedade como o mercado, também exercem poder de influência, de veto ou de apoio. Em outras palavras, as políticas públicas são condicionadas às interrelações entre economia, sociedade e política.

A despeito de toda essa complexidade, muitas políticas públicas são formuladas, decididas e implementadas. O que torna possível contornar essa complexidade e gerar uma política pública? Ou melhor, o que torna possível colocar o "Estado em ação"? A resposta está nas características das instituições. Isso porque não só as estruturas econômicas e sociais contam, mas as instituições (regras) são uma variável crucial na formulação e implementação de políticas públicas. Instituições são formas de organização social e são compostas por regras formais e informais (rotinas, costumes, normas sociais, cultura) que modelam os resultados da ação dos atores e dos governos. As instituições geram incentivos e restrições impostos não apenas por fatores externos, mas também pelas regras que regem as decisões. As instituições definem a estrutura de recompensas e punições para diferentes estratégias, pautando o comportamento dos atores políticos e apresentam riscos e oportunidades previsíveis. Instituições definem regras que são utilizadas pelos indivíduos para determinar quem e o quê está incluído em situações de decisão, como se estrutura a informação, quais as ações podem ser tomadas e em que seqüência, e como as ações individuais são agregadas e transformadas em ações coletivas, as quais geram políticas públicas.

Para aqueles envolvidos com a temática das políticas públicas, em particular os que as analisam na perspectiva da Ciência Política, compreender essa complexidade e a influência das instituições do Estado sobre as políticas públicas é fundamental para o desenvolvimento de pesquisas bem desenhadas e de políticas melhor analisadas. 